\title{
Viking Expansion Northwards: Mediaeval Sources
}

\author{
TETTE HOFSTRA ${ }^{1}$ and KEES SAMPLONIUS ${ }^{2}$
}

(Received 24 February 1994; accepted in revised form 25 March 1995)

\begin{abstract}
Evidence for Scandinavian activities in the northwestern part of the Barents Sea is scanty; according to the Annals, Svalbar $\square(i)$ was discovered in 1194, but the entry refers to Jan Mayen rather than present-day Svalbard/Spitsbergen. By contrast, the southern fringe of the Barents Sea was more than once crossed by Vikings on their way to Bjarmaland (Russia) in the White Sea area. As early as the end of the ninth century, an Old English source tells of a Norse expedition to that area and Old Norse sources indicate the existence of trade links back to the tenth century, possibly even earlier. The commodities traded and levied were tusks, precious furs and skins. The trade, also with the nearby Sami, was controlled by Norse chieftains living on the coast south of Troms $\varnothing$, who competed for power with the kings of Norway. Both kings and chieftains were involved in the Bjarmaland expeditions, as can be seen from historical sources and from fiction. A final expedition took place in 1222.

The trips to Bjarmaland did not lead to correct ideas about the geography of the Barents Sea area as a whole. Firm knowledge was limited, leaving room for superstition and learned speculations, such as a land-bridge to Greenland and a race of arctic giants, thought to live somewhere north of Bjarmaland. As to the Barents Sea proper, the sources reflect problems with sailing.
\end{abstract}

Key words: Middle Ages, White Sea, Bjarmaland, Russia, Vikings, Norse, Sami, trade, superstition

RÉSUMÉ. On ne possède que très peu d'indices attestant des activités scandinaves dans la partie nord-ouest de la mer de Barents. Selon les chroniques, le Svalbar】 fut découvert en 1194, mais l'entrée se réfère à Jan Mayen plutôt qu' au Svalbard/Spitzberg de maintenant. Par contre, la bordure méridionale de la mer de Barents a été traversée plus d'une fois par les Vikings en route vers le Bjarmaland (Russie) dans la région de la mer Blanche. Dès la fin du IX ${ }^{\mathrm{e}}$ siècle, un document en vieil anglais rapporte une expédition norroise dans cette région et des documents en vieux norrois révèlent l'existence de liens commerciaux remontant au $\mathrm{X}^{\mathrm{e}}$ siècle, peut-être même avant. Les objets échangés et prélevés consistaient en défenses, fourrures précieuses et peaux. Le commerce, qui se faisait également avec les Samits tout proches, était contrôlé par les princes norrois habitant la côte au sud de Troms $\varnothing$, qui luttaient pour le pouvoir avec les rois de Norvège. Rois comme princes participèrent aux expéditions du Bjarmaland, comme en attestent les sources historiques et les ouvrages de fiction. Une dernière expédition eut lieu en 1222.

Les voyages au Bjarmaland ne permirent pas de se faire une idée juste de la géographie de la mer de Barents en général. On ne savait pour sûr que peu de choses, ce qui laissait place à la superstition et à des suppositions acquises, telles que l'existence d'un pont continental vers le Groenland et d'une race de géants arctiques, qu'on croyait vivre quelque part au nord du Bjarmaland. Quant à la mer de Barents même, les sources historiques témoignent de problèmes concernant la navigation.

Mots clés: Moyen Âge, mer Blanche, Bjarmaland, Russie, Vikings, Scandinaves, Samits, commerce, superstition

Traduit pour la revue Arctic par Nésida Loyer.

\section{INTRODUCTION}

The Vikings-that is the expanding Scandinavians from the end of the eighth century onwards-were renowned for the skill in sailing that they displayed in large parts of Europe. The Barents Sea area certainly was within the scope of some mediaeval Scandinavians, for Halogaland in northern Norway was settled by Norwegians, and Finnmark (Old Norse Finnmörk) seems to have been visited frequently by them (Fig. 1). Sailing was a common way of travelling, and it appears that at least the southwestern shore of the Barents Sea was known to them.
This paper intends to give an impression of the way in which the Norsemen moved north and penetrated the arctic waters. First we discuss some of the written mediaeval sources that are related to Arctic Norway and the Barents Sea area, and look for some general pattern. Next we compare our findings with those of archaeological research, and look at the recent social anthropological approach. As we are primarily concerned with written sources, these two last disciplines are used only as auxiliaries. In a final section we look at the mediaeval speculation with respect to the area, such as the notion of a north-continent and the occurrence of fabulous creatures.

The term mediaeval will be used in a general sense.

\footnotetext{
${ }^{1}$ Vakgroep Scandinavische Talen en Culturen en Oudgermanistiek, Faculteit der Letteren, Rijksuniversiteit Groningen, Postbus 716, 9700 AS Groningen, The Netherlands

${ }^{2}$ Bestevaerstraat 39, 1056 HG Amsterdam, The Netherlands

(C) The Arctic Institute of North America
} 


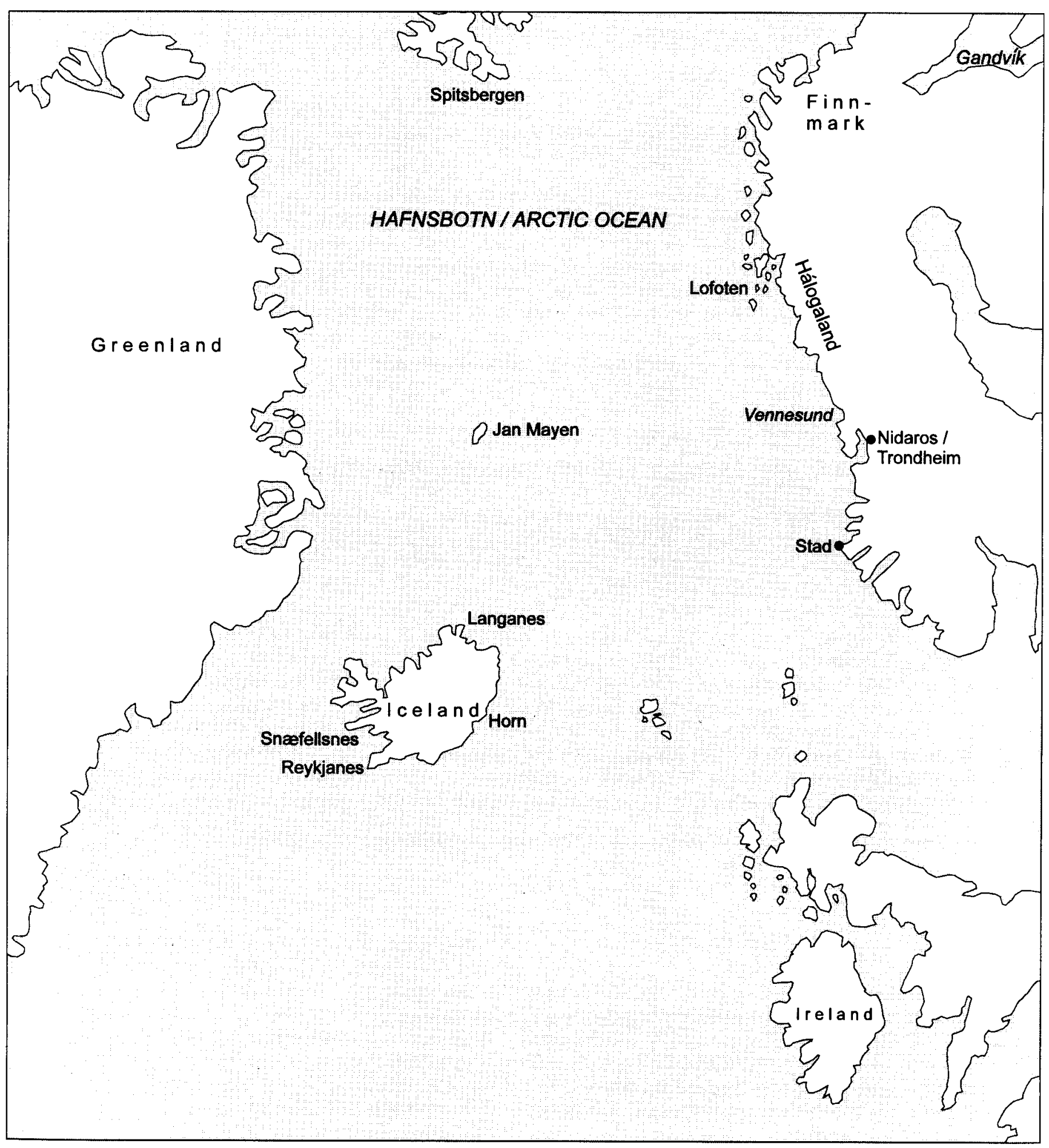

FIG. 1. Place names mentioned in the discussion of SvalbarDi.

Likewise, the concept Barents Sea area is applied liberally, used here as including the waters round Spitsbergen. The words Vikings and Norsemen are used interchangeably.

As mediaeval data concerning the Barents Sea as a whole are scarce, the focus will inevitably be on its southern fringe, especially on the White Sea area (Fig. 2).

\section{THE PROBLEM OF SVALBARDI}

There is some evidence that the exploration of the northwestern part of the Barents Sea started late and was of an involuntary nature. In their entry for the year 1194, several Icelandic annals record the finding of Svalbar $\square$ or Svalbar $\square i$ 


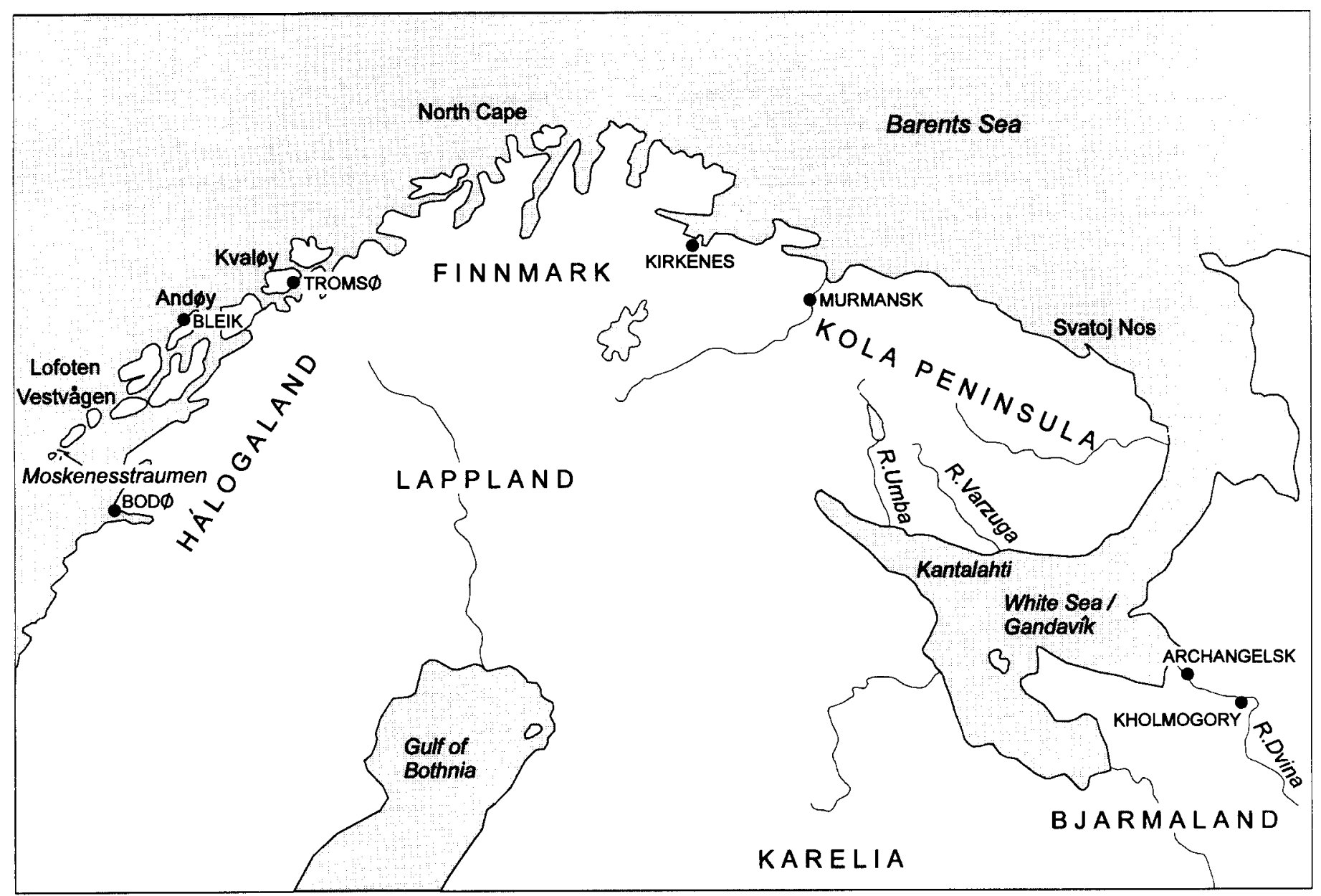

FIG. 2. Northern Norway and the White Sea region.

(Storm, 1888:22, 62, 121, 181). Unfortunately, the location of this $\operatorname{Svalbar} \square(i)$ is a matter of dispute. Landnámabók (The Book of Settlements), a thirteenth-century compilation of records about the first Icelandic settlers and their progeny, informs us (chapter 2) that:

According to learned men it takes seven days to sail from Stad in Norway westwards to Horn on the east coast of Iceland, and from Snæfellsness four days west across the ocean to Greenland by the shortest route. ... From Reykjaness in South Iceland it takes five [varia lectio: 'three'] days to Slyne Head in Ireland, four days from Langaness in North Iceland northwards to Svalbar $\square i$ in the Arctic Sea. (Pálsson and Edwards, 1972:16; cf. Benediktsson, 1968:32-35)

The quoted text was compiled by the Icelandic historian Sturla DórDarson (d. 1284). The variant reading Driggja "three" instead of fimm "five," can be found in the version from Hauksbók, a manuscript written in the years 1306-08.

In his 1900 edition of Landnámabók, Finnur Jónsson confidently identified the Old Icelandic Svalbar $\square i$ with Greenland's east coast, but in later writings he added a question mark to it (Jónsson, 1900:316, 1925:165). Nowadays, the notion finds no supporters. Other locations that have been put forward are Jan Mayen and the west coast of Spitsbergen. As it is natural to associate the Old Icelandic SvalbarDi with present-day Svalbard, the burden of proof rests with those scholars who argue otherwise. The Icelandic historian, Jón Jóhannesson (1956:130), preferred Jan Mayen on the grounds that the recorded period of four doegr would have been too short a time to sail from North Iceland to Spitsbergen. Remarkably enough, Pálsson and Edwards (1972:16, note 7) use the same argument of recorded days' sail to justify their identification of SvalbarDi with Spitsbergen.

The confusion emerges from the fact that Old Icelandic doegr means both "day of twenty-four hours" and "a period of twelve hours." Used in the latter sense, seven doegr of sailing, the time needed to sail from Norway to Iceland according to Landnámabók, would be 3.5 days' sailing. As the shortest distance is 525 nautical miles (Morcken, 1968:398), one day's sailing ( = two doegr) amounts to 150 miles (ca. 278 $\mathrm{km})$. Morcken (1968:399) and Binns (1980:86) figure that 144 miles $(266 \mathrm{~km})$ must have been the distance that was reckoned as one day's sailing. This reckoning would leave us with 288 , say 300 miles $(556 \mathrm{~km})$ to reach Svalbar $D i$, consistently reported north of Iceland at a distance of four $d \propto g r$ sailing in all versions of Landnámabók. This clearly won't 
bring us to Spitsbergen, but it accords well with Jan Mayen, situated 311.6 miles $(577 \mathrm{~km})$ distant. However, the matter is complicated by the fact that the Landnámabók records the time needed to sail from Iceland to Ireland, some 700 nautical miles (1296 km), as five dogr. Here dogr appears to denote a period of 24 hours. Used in that sense, four dogr of sailing, the time needed to get from Iceland to $S v a l b a r D i$, would correspond to 576, at the most 600 miles $(1112 \mathrm{~km})$. Even so, it falls below the distance of 835.5 miles $(1547 \mathrm{~km})$ one has to cross to reach Spitsbergen from Iceland. So, if the sailing time of four doegr recorded by Landnámabók is authentic, and provided this $S v a l b a r D i$ is identical with the one mentioned in the annals, we have no choice but to link the 1194 discovery with Jan Mayen.

The Historia Norwegia (History of Norway), possibly written around 1200, records (chapter 1) that some sailors on their way back from Iceland to Norway encountered strong headwinds that drove them north to a frosty region (plaga brumalis), where they came upon land between Greenland and Bjarmaland (Storm, 1880:75). The land they found may well be identical with the SvalbarDi of the annals. If, however, the Historia Norwegia was written earlier in the twelfth century, as has been argued by some scholars, and provided the story has a basis in reality, then the new-found land may refer to another place, viz. Spitsbergen (cf. Jóhannesson, 1956:130). Whether the reference is to Spitsbergen or to Jan Mayen, the discovery was clearly not followed up by a systematic survey of the land, as had happened with Iceland and Greenland; its inhospitable conditions were apparently too evident to stimulate any proper exploration, and when it came to describing the new land, the anonymous author resorted to general ideas about half-mythical creatures believed to live far north, people of giant stature and women who got pregnant through a drink of water. The folkloristic nature of the description makes it unwise to attach much importance to it; even so, we can deduce from the note first, that the discovery was accidental and, second, that interest was limited. The same applies to the finding of Svalbar $\square i$ in 1194 , as recorded in the annals: the account may indicate some degree of Scandinavian activity in the Arctic Ocean, but this discovery was definitely late in comparison with the finding of Iceland (870 AD) and Greenland (986 AD). Chronologically, the discovery coincided conspicuously with the rise of commercial fishing, but whether there is any connection is hard to say.

To judge from the written sources, sailing the Barents Sea was no objective in itself, at least not until the end of the twelfth century. Making a living was probably the main concern for most people, and sailing these wind-swept northern seas out of curiosity was an enterprise only few could afford. There is, however, one notable exception. In chapter 39 of his Descriptio Insularum Aquilonis (ca. 1075/1080), Adam of Bremen, after having quoted the statement of Martianus Capella (ca. 400 AD) that beyond Thule the sea is congealed after one day's navigation, continues by saying that King Harald the Hardruler (d. 1066) tried to find out if it were true:
The very well-informed prince of the Norwegians, Harold, lately attempted this sea. After he had explored the expanse of the Northern Ocean in his ships, there lay before their eyes at length the darksome bounds of a failing world, and by retracing his steps he barely escaped in safety the vast pit of the abyss. (Tschan, 1959:219; cf. Lund, 1978:63)

The text gives no cause for doubting that Harald sailed the sea north of Iceland or Norway. It is a matter of dispute whether Thule refers to Norway or to Iceland. Adam of Bremen uses the term repeatedly in the latter sense, but he appears to have been the first author to do so. If the abyssus of the Latin text is identical with a notorious tidal current (ON röst) mentioned in several reports of voyages to Bjarmaland, or with the legendary Moskenesstraumen in theLofoten(Tennant, 1951:18), then the reference must be to northern Norway.

Harald's enterprise shows that the scope and the character of the arctic waters were the subject of debate and, further, that firm knowledge about the Barents Sea region and the Arctic Ocean was still limited in the eleventh century, leaving ample room for speculation and fantasy.

\section{THE WHITE SEA REGION}

For the southern part of the Barents Sea, sources are richer (Fig. 2). In the preface to his Gesta Danorum (History of the Danes), probably written between 1208 and 1218, the Dane, Saxo Grammaticus, pays some attention to the geography of Arctic Norway. It is clear that Saxo had informants with some knowledge of travelling to the White Sea area when he wrote that the Ocean "increases in breadth as it streams eastwards along the coastline of northern Norway till it is walled by an unbroken arc of land and terminates in a sea which our ancestors called Gandvik" (Davidson and Fisher, 1979:8-9).

From several Old Norse texts it appears that a region called Bjarmaland was visited by Norwegians; the way to Bjarmaland, which is located at the edge of the White Sea, leads via the Barents Sea. The White Sea itself is called Gandvík (or sometimes Grandvík); Gandvík can be compared with the Finnish name Kantalahti "Kandalakshkaya Guba," a bay in the northwestern part of the White Sea; Finnish -lahti and Old Norse -vík both mean "bay." It has been thought that kanta- represents the Old Norse word gand "magic," which could suggest an Old Norse background of the place, but another possibility is that kanta-represents a Siberian placename element (cf. Simek, 1990:204) or that it is identical with Finnish kanta "base."

The reading Grandvík "Danger Bay" or "Guileful Bay," if representing a folk etymology, shows that the White Sea area was not a favourite destination. Lack of appreciation is also clear in the use of Gandvík in a kenning (a poetic description) of the giant race called Gandvíkr Skotar "Scots [= people] of the White Sea" by the poet Eilífr GoDrúnarson in the late tenth century (Jónsson, 1912:139). 
A low opinion of the land in this area is certainly expressed by Saxo, who in Book VIII of his Gesta (ca. 1200) describes the landscape as "a region of everlasting cold, spread with deep snows, for it does not experience the sun's vigour even in summer. Abounding in trackless forests, it is incapable of producing crops and is haunted by animals uncommon elsewhere. There are many rivers, whose courses are churned into foam of roaring rapids by reefs embedded in their channels" (Davidson and Fisher, 1979:263).

\section{A NON-SCANDINAVIAN SOURCE FROM THE NINTH CENTURY}

The earliest reference to Viking voyages to the White Sea area is found in an Old English text from the ninth century, and concerns a trip made by Ohthere, a Norse chieftain from Halogaland. Ohthere's journey to the White Sea area via the southern fringe of the Barents Sea must have taken place somewhere between 870 and 890 A.D. (Vaughan, 1982:316). Ohthere was a formidable voyager by all standards; after his trip to the White Sea, he sailed to the Baltic, then to England, where he visited Alfred the Great of Wessex (d. 899), to whom he described his travels. Alfred incorporated Ohthere's account into the Old English translation of Orosius' Historiae adversum Paganos. Its text has been edited by Ross (1981:1622) and Bately (1980:13-16); a Modern English translation is offered by Ross (1981:17-23) and Pritsak (1981:692-699).

Ohthere is quoted as saying that in Halogaland nobody lived north of him. He is described as wealthy in those things on which the wealth of the Halogaland people depended, that is, in herds of domesticated animals. When he visited King Alfred, he possessed 600 domesticated reindeer; but although he was a prominent man, he had no more than 20 cows, 20 sheep and 20 pigs. He had a little piece of arable land that he ploughed with horses, but cereal-growing did not amount to much. The economy of the Halogaland settlers depended above all on stock-raising and hunting (including whaling), in addition to taxes payed by the Sami in the form of furs (of marten, reindeer, bear, otter), birds' down, and ship's cables made of walrus hide and seal hide.

Apart from exploration of the land, the Old English text mentions the hunting of walruses for tusks as a reason for Ohthere's trip to the White Sea. Ohthere carefully mentions how many days he sailed and in which direction; it appears that from time to time he had to wait for favourable winds. After having reached the North Cape, he sailed due east for four days with western and northern winds. After having turned to the south and sailed for five more days with northern winds, Ohthere and his company reached a large river. They sailed up into the land, but didn't dare to go beyond that river, for fear of battle, because the land on the other side of the river was a cultivated [or: inhabited] area. The land of the Beormas [Bjarmians] was the first settled or cultivated area Ohthere had seen since he left Halogaland.

It is not clear how far Ohthere's expedition went. The big river that halted him might be the Varzuga River, or the Umba
River, but probably not the River Dvina (Jansson, 1936:41), as has been argued by some. The fact that the right bank of the Varzuga River has a conspicuously richer vegetation accords well with Ohthere's description (Binns, 1961:49). Still other rivers have been proposed; for a more complete account, see Bately (1980:185-187) and Pritsak (1981:694, note 42).

A keen observer, Ohthere discerned two different peoples, the so-called Bjarmians (Beormas) and the Terfinnas (probably the Kola Sami). The Bjarmians were farmers; the nomadic Terfinnas were not. The land of the Terfinnas is described as completely uninhabited [or: uncultivated] except for the dwellings of the fishers, the hunters, and the fowlers. It is a pity that Ohthere apparently passed only knowledge on observed phenomena to King Alfred. For example, the account of his voyage doesn't contain the many stories the Bjarmians told him about their own land or the neighbouring countries, because Ohthere did not know what of it was true, not having seen it with his own eyes.

This first report of a trip to the White Sea is simultaneously the fullest account we have. It has been speculated that Ohthere's reason for going to Bjarmaland was, in effect, furtrade rather than curiosity (Johnsen, 1934:129; Pritsak, 1981:693, note 40). Ohthere's account gives us a good example of what expeditions could have looked like in those days. Details may have been left out, but the text, as it stands, is more reliable than any of the data found in Old Norse sources: it is almost contemporary; it is descriptive; and it appears to be accurate.

\section{SCANDINAVIAN SOURCES IN THE VERNACULAR}

In marked contrast, the Old Norse sagas, dealing mostly with events of the tenth century, were not written down before the year 1200 A.D., at least two hundred years after the events they describe. Sagas are not absolutely reliable journalistic or even scientific accounts. Many of them certainly have a historical basis, but when it comes down to it, they are fiction, and it would be unwise to accept their testimony at face value. The question of the historical veracity of the Icelandic sagas, especially the so-called Icelandic family sagas (Íslendingasögur), is one of the most debated issues of saga research (Hallberg, 1962; Durrenberger, 1991). Of the various kinds of saga literature, only the Kings' sagas, dealing with the deeds and achievements of the kings of Norway, and the so-called fornöld-sagas, describing events that predate the Norse migration to Iceland, have something to say about voyages round the North Cape. The information they contain will be looked at below.

Generally regarded as more reliable is the testimony of socalled scaldic poetry, i.e., poetry made by a scald (Old Norse skáld). Scalds were Norse and Icelandic poets, who were often in the service of the Norse kings about whom they composed poems. The king is praised, or commemorated, for his fierce courage and his ability to "redden his sword." It needs some training to evaluate these poems. Allusions like "the king feasted the ravens and the wolves [beasts that feed 
on the slain]" are characteristic of scaldic poetry, and we must not take them too literally. But occasionally the poet (e.g., Glúmr Geirason, below) is more specific, offering us an uncomfortable glimpse of what really may have happened.

\section{KINGS' SAGAS}

Voyages to the White Sea region are mentioned in Heimskringla, a collection of sagas about the kings of Norway from primaeval times to the days of King Sverrir, who succeeded to the throne in 1177. The author is the Icelandic politician, mythographer, and man of letters, Snorri Sturluson (1179-1241).

One of the sagas in Heimskringla is Haralds saga hárfagra, the saga of Harald Fairhair, the king who, probably at the end of the ninth century, made Norway a political unity. Harald gave five so-called longships to his favourite son, Eirik Blood-Axe. The twelve-year-old boy first raided in the Baltic, Denmark, Northern Germany and Friesland for four years, and after four more years of harrying in Scotland, Wales, Ireland and France, he set sail to the north: "Then he sailed north to Finnmark and all the way to Bjarmaland where he fought a great battle and was victorious" (Hollander, 1964:86; cf. ADalbjarnarson, 1941:134).

According to the saga Eirik was twenty years old when he sailed with his ships to the White Sea. As he was born around 895, his visit to the region took place around 1015.

Probably the same trip to the White Sea is mentioned in chapter 37 of Egils saga Skallagrimssonar. This saga, written in the first half of the thirteenth century, is usually reckoned as one of the Icelandic family sagas, although it in many ways resembles a Kings' saga. Here it is said that: "Eirik fought a great battle on the Dvina in Bjarmaland, and was victorious as the poems about him record. On the same expedition he obtained Gunnhild, the daughter of Ozur Toti, and brought her home with him" (Fell, 1975:53; cf. Nordal, 1933:93).

The first Norwegian king to visit Bjarmaland was Eirik Blood-Axe's son Harald, nicknamed Greycloak (gráfeldr). The designation "greycloak" refers to the cloak of squirrel fur Harald used to wear. The story of the journey he made ca. 965-970 is told in Haralds saga gráfeldar (chapter 14), as part of Snorri's Heimskringla: "One summer Harald Greycloak sailed with his fleet north to Bjarmaland, harried there, and had a great battle with the Bjarmians on the bank of the Dvina River in which Harald was victorious and killed many people, whereupon he plundered the land far and wide and acquired an immense amount of property" (Hollander, 1964:140; ADalbjarnarson, 1941:217).

The Icelandic poet Glúmr Geirason lived at Harald's court and, according to Haralds saga gráfeldar (ADalbjarnarson, 1941:198), was a man of great prowess. He commemorated Harald's victory in a poem, thought to have been composed around 970 A.D. The stanza gives us a vivid picture of a Viking victory over the Bjarmians, as can be seen from the prose translation made by Ross:
The subjugator of kings, bold in words, reddened the sword in the East, north of the burning settlement, where I saw the Bjarmian people run; the setter of treaties among men obtained fame on that expedition; the young prince had a battle on the Dvina's bank. (Ross, 1981:29)

It has been disputed whether this stanza originally belonged to the Gráfeldardrápa or was part of a poem on the already mentioned Eirik Blood-Axe. Its contents and its word choice, however, fit well in the Gráfeldardrápa (Fidjestøl, 1982:230-233).

It is hard to say whether violent actions such as the one pictured by Glúmr Geirason were common practice. Glúmr certainly did not shun exaggeration, as is shown by the flamboyant kenning "Odin of the sword" (hjalta malmÓ (inn), but clearly the stanza refers to fierce fighting. There is, however, more to it: in the sagas, trade is mentioned only in connection with narrative events, and scaldic praise of royal belligerence may well be over-represented in our sources, especially since the sagas are often based on scaldic stanzas, too. Ohthere's expedition is possibly more characteristic of normal contact with the White Sea area than any of the enterprises recorded in Old Norse literature. On the other hand, we must not forget that if Ohthere had been involved in plunder and pillage, it would have been unwise for him to state so to Alfred the Great, the great opponent of Viking plundering.

A more extensive account of a voyage to Bjarmaland is found in chapter 133 of Snorri Sturluson's Ólafs saga hins helga, a saga of St. Olaf (d. 1030), written ca. 1225. This king had to cope with strong opposition, and was eventually forced to flee into exile. One of his chief opponents was Thorir the Hound, a chieftain from Halogaland.

The saga informs us that king Olaf and Karli, an inhabitant of Halogaland, agreed upon a joint investment ( $50 \%$ financial participation) in a commercial expedition to Bjarmaland. Karli left Trondheim early in spring and set sail to Halogaland. His crew consisted of nearly 30 men, among them Karli's brother, Gunnstein, who brought his own merchandise. Thorir the Hound, on learning that Karli and Gunnstein intended to go to Bjarmaland, decided to join them with a ship of his own. Karli and Gunnstein agreed to this, but on the condition that apart from the merchandise each of them had, goods that would be acquired should be divided equally between the two ships. Contrary to what had been arranged, Thorir brought eighty men with him, instead of twenty-five, as Karli and Gunnstein did. The two ships met at Sandvær (west of Kvaløy, near Tromsø); they got favourable winds and got to Bjarmaland without problems. Trade was going extremely well, as chapter 133 tells us:

When they arrived in Bjarmaland they put into a market town, and dealings [with natives] began. All those who had merchandise along sold it at full value. Thorir acquired an abundance of grey furs as well as beaver and sable pelts. Karli also had a very great amount of wares along, with which he bought many furs. When the market closed they left by way of the Dvina, and then the truce with the 
people of the land was declared to be at an end. (Hollander, 1964:404; cf. ADalbjarnarson, 1945:229)

On the high seas a meeting of the crews was called. It was decided to go on inland and take booty. Thorir led his men to an enclosure with a mound and a statue of Jomali, the god of the Bjarmians. Both mound and statue were plundered, and a huge amount of silver and gold was taken away. The Norwegians escaped from the pursuit by the Bjarmians and sailed away. In the following, the saga gives some information about the sea voyage (Ólafs saga helga, chapter 133):

Then both sailed across the White Sea. The nights were still light, so they sailed both day and night until Karli one day in the evening put to shore by some islands, where they lowered the sail, cast anchor, and waited for the falling of the tide, because there was a strong current in the sea ahead of them. (Hollander, 1964:406; cf. ADalbjarnarson, 1945:232)

On the way home hostilities broke out between the crews of the two ships, leading to the death of Karli, and causing further troubles. The historical background of the conflict is probably the struggle for control of the profitable fur trade with the White Sea area, as will be discussed below.

The marketplace on the bank of the Dvina has been identified by Brøgger (1928:32) and others with Kholmogory, southeast of present-day Arkhangelsk, which was formerly called Novy Kholmogory. The Kholmogory region is one of the oldest settled places we know of in northern Russia. Kholmogory as a town seems to have been founded in 1353 (Vaughan, 1982:320), yet the settlement was already mentioned in a charter of the first half of the fourteenth century and may be even older.

The name Jomali, recorded by the saga as the name of a Bjarmian deity, is identical with the word for "god" in Baltic Fennic languages, e.g., Karelian and Finnish jumala "god." Ross (1981:48-50) takes the name Jomali as evidence that the Dvina-Bjarmians were Baltic Fenns, but the ethnicity of the Bjarmians is still much disputed. They have also been identified as Komi or Karelians (cf. Odner, 1985:4).

The earlier Legendary Saga of St. Olaf, written shortly after 1200 , is silent about the king's participation in a commercial trip to Bjarmaland. Here we read in connection with rebellious factions in Norway that Thorir the Hound, a mighty man, travelled to Bjarmaland and killed a brave man called Karli (Heinrichs et al., 1982:108-109).

It looks as if the Vikings usually visited the Barents Sea area only after having gained experience with sailing on other seas. Apparently a trip to the White Sea region was regarded as a sign of manly virtue that enhanced one's fame greatly. When king Hakon Magnusson, who reigned over the Trondheim district at the end of the eleventh century, died at the age of twenty-five, it is stated in Heimskringla that: "He was one of the chieftains who was most beloved by all the people in Norway. He had travelled north to Bjarmaland, had fought there, and won a victory" (Hollander, 1964:670; cf. ADalbjarnarson, 1951:212).
The prestige of a succesful trip was not unjustified, for, as Binns (1961:52) notes, to sail to the White Sea required considerable skill, but to sail back home even more so. One had to overcome a hostile current along the Murmansk coast, with only light winds to help. It may well have meant that hundreds of miles had to be rowed. Binns even doubts that the passage could have been made with longships.

This observation, together with the high prestige a successful voyage enhanced, calls for caution as regards travels to Bjarmaland alluded to in Old Norse literature. Not all such allusions necessarily reflect reality. The hero Örvar-Odd, who won fame as a youth by leading a Viking expedition to Bjarmaland, was asked on several occasions in his long life: "Are you that Odd who travelled to Bjarmaland a long time ago?" (e.g., Boer, 1892:28,33,44; cf. Edwards and Pálsson, 1970). Here the motif has got literary overtones, as it has in Njáls saga, where Hallvard the White presents his trip to Bjarmaland as a sign of skill and prowess (Sveinsson, 1954:75). Even so, there can be no doubt that Norwegian upper-class people (Ohthere, several kings, and other people of royal descent) took part in voyages to the land of the Bjarmians. Whether these trips took place on a regular basis is hard to say, since in Old Norse literature they are only mentioned in a broader narrative context. Traffic to the White Sea area may well have been more frequent than the sagas would make us believe. If so, the settlement of Vagan (in Lofoten) may, as suggested by Bertelsen, have served as a transit station from which expeditions to the White Sea were organized (Urbanczyk, 1992:131).

Ohthere's account and the references contained in the Kings' sagas make it clear that in the tenth and eleventh centuries the Barents Sea was economically important in the sense that it linked Norway with the White Sea area. It was the trade between those two regions that counted, not the Barents Sea in itself.

Between Norway and Bjarmaland lay Finnmark, thinly populated by Sami (or Lapps). The commodities obtained from the Sami were very much of the same kind as those provided by the Karelians and the Bjarmians. A look at the developments in Finnmark may give us an idea of the characteristics of the Viking expansion northward. According to Alfred the Great, Ohthere possessed a herd of six hundred reindeer, of which six were decoy reindeer. Now, no Viking normally had livestock that consisted of reindeer, animals that required special skill and experience to keep. Apparently Ohthere had Sami servants to do the job for him. It probably characterizes the way in which the Norsemen lived among the Sami, though his situation may reflect a later stage of the process. The exploitation of the resources of Halogaland and Finnmark for export purposes must have been initiated by Norse traders who settled among nomadic Sami and employed their services. The Historia Norwegiae records that the inhabitants of Halogaland, regarded as including Finnmark, lived mostly together with Sami and traded with them (Storm, 1880:78). In Snorri Sturluson's Olaf's saga helga, one Norse chieftain in Halogaland is described as having a group of several hundred Sami that supported him. It appears that the 
Norse settlers that had moved up north in due course obtained the rights of local chieftains. These relations must already have been established in the ninth century, since Ohthere speaks of the tributes he received from the Sami: "Each one pays according to his rank" (Bately, 1980:15; cf. Pritsak, 1981:696). This can only mean that already in Ohthere's days the Sami were taxed according to certain fixed rates. This tax may or may not have been a forerunner of what in later literature and charters was called finnskatt. Trade as a means to obtain skins and other valuable commodities from the Sami is recorded in Egils saga (chapter 14):

Thorolf went to Lappland again and had over a hundred men with him. He did as he had done the winter before, arranged trade with the Lapps, and explored large tracts of the forest country. (Fell, 1975:18)

The mention of trade, and especially finnskatt, in Egils saga and other written sources led scholars to regard the early mediaeval Sami as peaceful hunters and fishers, who were heavily exploited by ruthless Vikings. It found support, it seemed, in a range of later sources, of which Sebastian Münster's Cosmography (1544 A.D.) may serve as an example: "They [the Sami] had long been free until the Norwegians and Swedes subjugated them by force and forced them to pay a yearly tribute of costly skins of small animals" (Tennant, 1951:186). The references in saga literature, together with later records about the tribute the Sami had to pay, seemed to justify that in the time of the Vikings the relation between the Norsemen and the Sami was asymmetrical and exploitative.

Recently, however, archaeologists and social anthropologists have started to question the validity of this philological approach. Already Sjøvold (1974) took a more cautious stand, but a real eye-opener was Stenvik's article published in 1980 , in which the author describes the excavation of a Viking ship-burial at Lekanger (south of Bodø). What made the find remarkable was that geological conditions (calcareous soil) had caused the skeleton to be extremely well preserved. Analysis of the remains showed clearly that the buried man possessed features that we now regard as characteristic for Sami ethnicity (Stenvik, 1980:129). The fact that a Sami could get an upper-class ship-burial meant that the long-standing concept of better-organized Viking brutes versus primitive, defenceless Sami urgently needed revision. The signal was readily picked up. Odner (1981:28), who may have reached his conclusion independently, wrote shortly afterwards that the relation between the Norsemen and Sami may well have been symbiotic, rather than necessarily exploitative, as had been assumed. In his 1983 book Finner og terfinner, Odner presented a completely new concept of the dealings between Norsemen and Sami during the Viking period. It was, he says, a time of cooperation and specialization, each group having its own ecological niche and accomplishing a surplus production in its own way, to the mutual benefit of both parties. This system gave them access to resources that otherwise would have been hard to get at. The Norsemen received valuable furs, to be exported southward or used at home in the social prestige sphere, while the Sami got grain and iron implements used in hunting and fishing. Descriptions of small armies moving into Sami territory to enforce tribute, as found in Egils saga, are dismissed by Odner (1985:6) as instances of "impression management." This cannot be ruled out, but the descriptions may equally well reflect thirteenth-century conditions, when the Karelians frequently attacked Norse collectors of furs, or the other way around. Whatever the background, Odner is certainly right that "a noisy and conspicuous raiding party would have been easy to spot from long distances by the nimble-footed hunters" (Odner 1985:6, similarly 1981).

Another indication of Norse-Sami reciprocity is provided by metal hoards (some of them containing Norse silver coins) found in territory inhabited by the Sami. These finds were formerly thought to represent Norse activity, but modern archaeological scholarship tends to treat them as Sami deposits, perhaps of a sacrificial nature (Zachrisson, 1985:22). If this interpretation is correct, it means that these Sami, collectively or individually, had been able to accumulate wealth, some of which had even come from outside the area. It could be a sign that the egalitarian concept of equal access to resources was cracking, and that a process of stratification had entered Sami society (Urbanczyk, 1992:62).

Odner's idea of a Sami-Norse relationship based on cooperation has been widely accepted. Some scholars even claim that the relation involved more than just cooperation. In a recent article, Storli (1991) shows that the ornamental artefacts of eastern (i.e., Karelian or Gotlandic) provenance found in northern Norway, in grave mounds or as stray finds, are characteristic expressions of Sami culture. It is hardly remarkable that such artefacts have come to light in graves north of Troms $\varnothing$, since Norse settlements seem to have thinned out there entirely. More intriguing is their occurrence as grave goods in Viking grave mounds south of Tromsø. As the great majority of these places represent burials of women, Storli interprets the occurrence of these artefacts in a Norse environment as a sign of intermarriage between Norsemen and Sami women. The graves were sometimes richly furnished, and it is natural to link them to the Norse upper class. It is not unreasonable to assume that the women, too, were members of a Sami social elite. The conclusion is not really surprising. There is no reason why the Norsemen, moving up along the coast, should not have mixed with the indigenous population, both initially and later. Harald Fairhair himself married a Sami girl. The story, embedded in Heimskringla, sounds admittedly like a folktale, and scholars readily focus on its unhappy, folkloristic aftermath (Zachrisson, 1991:194), but careful reading shows unequivocally not only that Harald married the girl legally, but also that the later kings of Norway descended from this match. The "Norse" population of Halogaland may well have been of mixed origin, as the Lekanger boat-burial actually suggests. It must be noticed that the mighty jarls of Lade, who for a while held power in Norway, traced their lineage back to Samingr, said to be the son of Odin and the goddess Skadi, whose paraphernalia, skis and bow, are clearly reminiscent of the Sami way of living. 
The parallel is all the more striking, as Sami women are known to have been hunters on skis. Scholars nowadays disapprove of Müllenhoff's (1906:56) etymology of Samingr as "son of Sami," but if it can be shown that Sami was also pronounced with a long first vowel, they may well have to reconsider. Some upper-class layers of Sami may have chosen to live the life of the Norse cultural habitat.

The new model of Norse-Sami relationship still leaves much to be explained, not least how Ohthere's words about Sami tribute have to be understood; but even so, it has much to recommend it.

According to Urbanczyk (1992:196), it was only after the state of Norway succeeded in crushing the power of the arctic Norse chieftains that Sami-Norse relations deteriorated: "Economic cooperation and tolerance were replaced by an 'administrative' attitude and ideological aggression."

It took the central state almost a century to gain control of the north and make it subordinate to its interests. Around the middle of the eleventh century the process was formally completed, but even then royal power was often mainly declarative. Local power structures, represented by mighty families, were upheld during most of the twelfth century, and only the reforms carried through by King Sverrir put an end to it.

The powers exercised by the Norse chieftains undoubtedly amounted to a monopoly on external trade. Furs and skins and eiderdown were purchased from the Sami, or from the White Sea (Bjarmaland), an area that also yielded walrus tusks. These valuable commodities were exported to the European market in return for luxury goods like wine, honey and cloth. Remains of an early Viking Age chieftain's farm, found in Borg on Vestvågøy (an island in Lofoten), give us a glimpse of life up north: "An $80 \mathrm{~m}$ long building situated on a windswept hill had a magnificent view across the land and safe and easy access from the sea. The owners of the house had gold and silver, glass cups and fine jugs made in Western Europe. A short distance from the farm was a 'court-site' and a large naust (boathouse)" (Roesdahl, 1991:107).

The Norse chieftains in Halogaland apparently made a comfortable living by controlling the profitable fur trade, and it is only natural that they were loath to accept the increased royal power that resulted from the unification of Norway. In spite of the opposition of the chieftains, the kings made it law that north of Vennesund all trade in skins and furs of beasts of prey were a royal monopoly (Johnsen, 1934). The sagas report several clashes between the kings of Norway and the chieftains of Halogaland. They are of interest here because, as long as we find conflicts over rights and revenues, we may reasonably assume that the lucrative trade with the White Sea area continued. Of these conflicts, the one between Thorir the Hound and King Olaf is probably a good example of this kind of struggle for economic power. A last clash is reported from the early twelfth century, when a dispute over the revenues of the Sami taxes (collected in furs) broke out between King Sigurd the Crusader and his retainer, Sigurd Hranason. All this suggests that the collection of furs and skins from these northern areas continued during the whole of the Viking Period, and even up to the end of the eleventh century.
The archaeological data seem to corroborate this conclusion. The distribution of finds from the tenth and eleventh centuries shows a continuing activity northward along the Norwegian coast. On the northern shore of the Varangerfjord, several Norse (?) graves have come to light, all belonging to the Late Viking Period (Sjøvold, 1974). A well-equipped grave containing the skeletons of a male and a female was interpreted by Sjøvold as an indication of permanent settlement. Still more to the east, on the southern shore of the same fjord, a hoard of silver was found (Sjøvold, 1974), probably deposited by Sami. All these finds support the idea that traffic around the Kola Peninsula to and from the White Sea continued during the Late Viking Period. Following the seaway along the southern shore of the Barents Sea, trade continued, first as a monopoly of the mighty Norse chieftains of Halogaland, later as a disputed privilege of the kings of Norway.

\section{CHANGES AND CONTINUITY}

Icelandic annals, e.g., Annales regii, record for the year 1222 that "Andrés Shield-strap and Ivarr from Útvík made a foray to Bjarmaland" (Storm, 1888:126). Útvík is a place in Beitstad, north of Trondheim in Norway (Storm, 1888:645). The expedition was undertaken in retaliation for the slaying of a Norse merchant and his crew who had stayed in Bjarmaland during the wintertime. No reason for the murder is given, except that the merchant, Helgi Bograngsson, quarrelled with the king of the Bjarmians. Maybe the murder was instigated by competitors from Novgorod, who by now had started to dominate the area. Andrés' expedition is recorded more fully in Hákonar saga Hákonarsonar, written ca. 1265 (Kjær, 1911:371; Mundt, 1977:49). The document is of interest, because it contains the earliest account of a ship lost on the coast of Finnmark:

\footnotetext{
And as they moved southwards, they sailed into a strong current north of Straumneskinn, and three ships got out of it. But the ship Ivar was on got water in its sail, and the water turned the ship towards one side in such a way that the sea rushed in it, and it capsized immediately. Jogrim was the name of the man who got Ivar up the keel, and a third man managed to get on the keel by himself. From Thorberg's ship a boat was launched towards the ship, and the boat lost its prow, and Jogrim got them in the boat. And then Jogrim said that he did not see Thorstein, his comrade, and he jumped again in the sea-current and he died very bravely, and all the men who were on the ship died with the exception of only two, Ivar and a second man. A huge amount of goods was lost. (our translation)
}

According to Mundt (1977:234) Straumneskinn is Svjatoj Nos. The dangerously strong current is probably the same as the one mentioned in the quoted passage of Snorri's Olafs saga helga (Storm, 1880:79). If so, it must have been a spot notorious for its tidal currents. There is, however, a marked difference: Andrés and his men seem to have been taken by 
surprise, whereas Thorir the Hound and Karli cautiously waited for the right moment to cross. Their caution indicates familiarity with the sailing route, suggesting they used it more regularly than Andrés and his companions.

In Hákonar saga Hákonarsonar, the scribe ended his report of the expedition by saying that since then, no voyages to Bjarmaland had been undertaken anymore (Kjær, 1911; cf. Mundt, 1977: 47). Indeed, this expedition to Bjarmaland is the last one we know of; it appears that after 1200, connections with the White Sea area declined. There are several reasons for that. First, the climate seems to have become colder in the thirteenth century. The Dorgils saga og Hafli $\square$ a, probably composed after 1237 , recalls the first half of the twelfth century as follows: "In that time conditions were so good that the crops never failed" (Kålund, 1906:22). Written sources indicate that towards the end of the twelfth century, conditions became less favourable, and as we proceed into the next century, reports about drift ice increase (Lárusson, 1969). The deterioration must also have made itself felt in arctic Norway (cf. Urbanczyk, 1992), and as a consequence ice conditions in the southwestern part of the Barents Sea may have prevented expeditions from entering the White Sea. More importantly, the White Sea area, which had provided the Norsemen with valuable commodities, came under the overlordship of Novgorod, possibly around 1200 (Johnsen, 1934:131). Russian merchants appeared in the marketplaces on the Dvina. They saw to it that from then on Bjarmian/ Karelian furs went to Novgorod, from where they found their way to the rest of Europe (Sawyer and Sawyer, 1993). Already some commercial links had been established between Karelia and the Baltic, where Gotlanders were actively trading (Sawyer, 1962). These developments naturally affected the importance of the Barents Sea as a trade route between Western Europe and the White Sea. One would expect this interruption in the supply of furs to have led to an upsurge in the trade with the Sami of nearby Finnmark, but apparently this did not happen, at least not on a large scale. The trade certainly continued, as is proved by the treaty between Novgorod and the king of Norway in the year 1252, in which both parties forbade their subjects to raid collectors of furs that were operating in the service of the other. But although the fur trade continued for some time, it was no longer of prime importance, for a third development had now got under way. The Hansa had appeared in Norway, and fish was becoming the commodity money could be earned with. The unknown author of the Profectio Danorum, writing about the year 1191, reports that in Bergen "There are such amounts of dried fish, called cod, that it is beyond counting. Here one finds a great many people, who come here from Iceland, Greenland, England, Germany, Danmark, Gotland and many places more" (Johnsen 1934:137). Fishing can be traced back into the Viking Period, but as a means of subsistence its role was limited, except perhaps in some parts of Lofoten. Osteological analysis of deposits found at Bleik (on the island Andøya, ca. $69^{\circ}$ north latitude) suggests that the consumption of fish amounted to less than $10 \%$ of the caloric value of the diet, but this figure may be misleading (Urbanczyk,
1992:176). More importantly, in the Viking period, fishing was not undertaken in order to produce a surplus that could be exchanged for goods from outside. Now, toward the end of the twelfth century, all this changed. The rapid growth of continental towns led to increased demands for dried fish, and as a result the Barents Sea with its riches of fish, especially cod, gradually became an objective in itself.

\section{FICTION AND FANTASY}

In Old Norse literature, only the Kings' sagas, including Egils saga, display some knowledge of the islands and areas to the northeast of Scandinavia. Apart from the Kings' sagas it is only late legendary fiction that leads to those parts of the world, mostly for depicting marvels and hazardous encounters. One wonders what kind of tales Viking sailors brought home from their northern journeys. The trips to the White Sea seem to have enkindled fantasy, and with time the stories became more fantastic. Bjarmaland, described by Ohthere and the Kings' sagas as a place of trade, is recorded in other sources as a halfmythical country bordering Jötunheimr "Land of the Giants" (cf. Simek, 1986:251). A good example of this narrative tendency is found in Örvar-Odds saga. This saga belongs as a so-called Viking saga to the non-historical fornöld-sagas. In the oldest version now extant (written ca. 1300 A.D.), there is a short description of how slain Bjarmians are robbed of their weapons by the Norsemen. In a fifteenth-century version, the scribe has altered this into silver weapons, giving the episode fairy-tale overtones. Even more fantastic motifs are found in some of the other fornöld-sagas (Ross, 1981); here the historical data, if there ever were any, have given way to a narrative landscape of myth and fantasy.

\section{MAGIC}

In his Gesta (ca. 1200), Saxo also draws on popular lore and myth. In Book IX we hear of the magical charms which the Bjarmians address to the heavens so that Danes who travel in Bjarmaland are unable to put to sea for some time because of the raging thunderstorms; and then the Danes are tormented by a burning heat. The men's constitutions are broken by the two extremes of climate following one upon the other, and dysentery causes widespread death among the Danes (Davidson and Fisher, 1979:286).

Book I also contains a change of the weather caused by the Bjarmians' spell (Davidson and Fisher, 1979:31). The motif of bad weather and storm caused by means of magic is widespread in Old Norse lore. This magical power was also attributed to Sami and non-Christian Norsemen. Eirik's wife, the beautiful Gunnhild, turns out to be a sorceress, as could be expected with people from this area. But according to the Historia Norwegia, Gunnhild was the daughter of a Danish king, which is certainly closer to the truth (Fell, 1975). 


\section{LAND OF THE GIANTS}

In Saxo's Gesta (Book VIII) we find the familiar motif that Bjarmaland is inhabited by people of extraordinary stature, and we learn about a golden bridge over the river that divides the human world from the realms of the other world (Davidson and Fisher, 1979:263).

One of the versions of Hervarar saga (thirteenth century, manuscript from the seventeenth century) records in its opening chapter: "It is found written in ancient books that to the north beyond Gandvík it was called Jötunheimar, and Ymisland to the south between there and Hálogaland" (Tolkien, 1960:66). Accordingly, those regions were thought to be inhabited by giants and half-giants, Ymir being the ancestor of all giants, and jötunn being the Icelandic word for "giant" (cf. Tolkien, 1960).

The giants, the forces of chaos and destruction, were thought to dwell in the eastern and northern parts of the world. It is hard to say whether this concept is genuinely pagan. It may well have derived from mediaeval encyclopedic learning, which reached the North through early trade contacts, and thus predated Christianization proper. Ohthere's stay at Alfred's court amply testifies to the existence of such early contacts. The first reference to the idea of giants living up north is probably the late tenth-century kenning Gandvik r Skotar for "giants" mentioned above. Whether heathen or not, the idea of a "Land of the Giants" situated near Bjarmaland did not prevent people from sailing to the White Sea. If it belonged to popular belief, it apparently did not amount to more than usual superstition.

\section{A LAND-BRIDGE BETWEEN RUSSIA AND GREENLAND}

As mentioned earlier, in mediaeval Scandinavian compilations one comes across the idea of an uninhabited landmass forming a bridge between Bjarmaland and Greenland. According to Jakob Benediktsson (1960:267) the concept is found for the first time in the Historia Norwegia, written ca. 1200 or possibly earlier. The Latin text speaks of the Arctic Sea as septentrionalis sinus "the Northern Bay/Gulf." The Old Norse name for it, Hafsbotn, also touches upon an underlying concept of a sea fringed by land (Jóhannesson, 1960). There is perhaps no better indication of the prevalence of the northern concept of the Arctic as a land-fringed sea than the very use of this term. Apart from the term Hafsbotn, the oldest vernacular reference may be a short note in the "King's Mirror" (Konungs skuggsjá), probably written around 1250 (Halvorsen 1992:911), or a little earlier (Falk, 1971). Here, Greenland is said to be connected "with another continent" (áfast vi $\square$ önnur meginlönd), which certainly refers to the alleged land-bridge (Jóhannesson, 1956:130).

The idea of a land-bridge from Bjarmaland to Greenland recurs in several texts in the vernacular. A short world description, or landalysing, formulates it as follows:
North of Norway is Finnmark. From there the land turns to the northeast and then to the east until one reaches the land of the Bjarmians, which is tributary to the king of Novgorod [later Russia]. From Bjarmaland onward, the land goes to the uninhabited regions of the north till Greenland is reached. (manuscript AM 736 I, 4to, cf. Simek, 1990:431; our translation)

According to Jóhannesson (1960) this description dates from the end of the twelfth or the beginning of the thirteenth century; the text has been handed down in manuscripts from ca. 1300 onwards. Manuscript AM 194 8vo (dated 1387) mentions unsettled regions north of Bjarmaland stretching out as far as Greenland (Simek, 1986). Holm Olsen (1962:476) interprets the notion of the land-bridge as an indication that the large island groups in the northern part of the Arctic Sea were known.

The most remarkable record of a land-bridge in the Barents Sea area is the story found in the Landabók, in AM 779b, 4to. This manuscript dates from the seventeenth century, but its sources might be from the Middle Ages. Here too bays, glaciers, mountains and unsettled regions between Greenland and Gandvík near Norway are mentioned (Simek, 1990:588). And, as the story continues:

It is told in Icelandic books that a man came walking from
Greenland to Norway, across all those deserted areas of
glaciers and across uninhabited places, and this was
considered to be a great event. He brought with him a goat
and fed himself with her milk; therefore he was called
Goat-Hall from that time onwards. (our translation)

\section{CONCLUSION}

The Barents Sea as such plays no role in mediaeval descriptions or fantasies. It was of importance because it had to be crossed by whoever wanted to visit the White Sea area, where precious commodities, such as tusks or rare furs, were purchased. Situated in this area was a country called Bjarmaland, which is repeatedly described in Old Norse literature, sometimes in realistic terms, sometimes spiced with fairytale motifs. Viking Age trade with the White Sea area was controlled by Norse chieftains, who lived in the coastal areas south of Troms $\emptyset$. Relations with the Sami appear to have been good, possibly up to the point of intermarriage. It was only after the emergence of a central state and the imperative ideology that followed it that relations deteriorated.

Of the actual developments in Arctic Norway, little is reflected in Old Norse sources. The overall location of peoples and places seems fairly correct, but the events themselves are sometimes reinterpreted. Nevertheless, they are embedded in a narrative structure that contains old traditions: there were voyages to the White Sea, there was a lucrative fur trade, and there was a struggle between chieftains and kings.

Viking connections with the White Sea declined after 1200 , when the area came under Novgorod. Deterioriation of 
the climate may also have made the passage more difficult.

In several mediaeval writings we come across the idea of an uninhabited landmass stretching from Russia (Bjarmaland) to Greenland.

As to the Barents Sea itself, information is restricted to phenomena like unfavourable winds, or dangerous currents. An Old Norse literary text from the second half of the thirteenth century describes a shipwreck on the Finnmark Coast in the year 1222.

\section{REFERENCES}

AD ALBJARNARSON, B., ed. 1941, 1945, 1951. Snorri Sturluson. Heimskringla I. Íslenzk Fornrit Vol. 26, 27, 28. Reykjavík: Hi[ Íslenzka Fornritafélag.

BATELY, J., ed. 1980. The Old English Orosius. London: Oxford University Press.

BENEDIKTSSON, J. 1960. Geografisk literatur. Vestnordisk. In: Kulturhistorisk leksikon for nordisk middelalder fra vikingetid til reformationstid, Vol. 5. København: Rosenkilde \& Bagger. 266-268.

—., ed. 1968. Íslendingabók. Landnámabók. Vol. 1. Íslenzk Fornrit 1:1. Reykjavík: Hi] Íslenzka Fornritafélag.

BINNS, A. 1961. Ohtheriana VI: Ohthere's northern voyage. English and Germanic Studies 7:43-52.

. 1980. Viking voyagers: Then and now. London: Heinemann. BOER, R.C., ed. 1892. Örvar-Odds Saga. Altnordische SagaBibliothek 2. Halle a.S.: Max Niemeyer.

BRØGGER, A.W. 1928. Håløygenes Bjarmelandsferder. In: Festskrift til rektor J. Qvigstad 1853, 4 April 1928. Troms $\varnothing$ Museums Skrifter, Vol. 2. Troms $\varnothing$ : Troms $\varnothing$ Museum. 27-36.

DAVIDSON, H.E., and FISHER, P., transl. 1979. Saxo Grammaticus. The History of the Danes. Vol. I: English text. Vol. II: Commentary. Cambridge: D.S. Brewer.

DURRENBERGER, E.P. 1991. The Icelandic family sagas as totemic artefacts. In: Samson, R., ed. Social approaches to Viking studies. Glasgow: Cruithne Press.

EDWARDS, P., and PÁLSSON, H., transl. 1970. Arrow-Odd: A mediaeval novel. New York: New York University Press.

FALK, Hj. 1971. Militærvesenet - Klædedrakt - Hår og skjegg. In: Tveitane, M., ed. Studier over Konungs skuggsiá. Bergen: Universitetsforlag. 144-152. (Reprint from Falk, Hj. 1920. Om militærvesenet. In: Jónsson, F., ed. Konungs skuggsjá. Speculum regale. København. 92-100).

FELL, C., transl. 1975. Egils saga. London: J.M. Dent \& Sons Ltd. FIDJESTØL, B. 1982. Det norrøne fyrstediktet. Øvre Ervik: Alvheim \& Eide.

HALLBERG, P. 1962. The Icelandic saga. Translated by Paul Schach. Lincoln: University of Nebraska Press.

HALVORSEN, E.F. 1992. Konungs skuggsjá. Kindlers Neues Literatur Lexikon, Vol. 18. München: Kindler Verlag. 910912.

HEINRICHS, A., JANSHEN, D., RADICKE, E., and RÖHN, H., eds., transl. 1982. Olafs saga hins helga. Die „Legendarische Saga“ über Olaf den Heiligen (Hs. Delagard. saml. nr. ${ }^{\mathrm{II}}$ ). Heidelberg: Carl Winter Universitätsverlag.
HOLLANDER, L.M., transl. 1964. Snorri Sturluson. Heimskringla. History of the Kings of Norway. Austin: University of Texas Press.

HOLM OLSEN, A.G. 1962. Ishavsfart. In: Kulturhistorisk leksikon for nordisk middelalder fra vikingetid til reformationstid, Vol. 7 . København: Rosenkilde \& Bagger. 476-479.

JANSSON, V. 1936. Bjarmaland. Ortnamnssällskapets i Uppsala årsskrift 1:33-50.

JÓHANNESSON, J. 1956. Íslendinga saga I. [jóDvelDisöld. Reykjavík: Almenna bókafélagi

— 1960. Um haf innan. Saga 3 [1960-63]:17-28.

JOHNSEN, O.A. 1934. Norges Handel og Skibsfart i middelalderen. In: Schück, A., ed. Handel og samfærdsel. Nordisk Kultur XVI:B: Medeltiden. København: J.H. Schultz. 128-147.

JÓNSSON, F., ed. 1900. Landnámabók I-III. Hauksbók. Sturlubók. Melabók m.m. København: Det Kongelige Nordiske Oldskriftselskab.

1912. Den norsk-islandske skjaldedigtning. B. Rettet tekst. I. Bind. København: Gyldendalske Boghandel.

_ 1925. Landnámabók Íslands. København: Det Kongelige Nordiske Oldskriftselskab.

KÅLUND, K., ed. 1906. Sturlunga saga efter membranen KróksfjarDarbók, udfyldt efter ReykjarfjarDarbók. København: Det Kongelige Nordiske Oldskrift-selskab.

KJÆR, A., ed. 1911. Hákonar saga Hákonarsonar. In: Det Arnamagnæanske Haandskrift 81a Fol. (Skálholtsbók yngsta) indeholdende Sverris saga, Böglunga sögur, Hákonar saga Hákonarsonar. Kristiania: Den Norske Historiske Kildeskriftkommission.

LÁRUSSON, M.M. 1969. Hafís á fyrri öldum. In: Hafísinn. Reykjavík: Almenna Bókafélag. 306-312.

LUND, A.A., ed., transl. 1978. Adam af Bremen, Beskrivelse af øerne i Norden. Oversat og kommenteret. Højbjerg: Wormianum.

MORCKEN, R., 1968. Norse nautical units and distance measurements. In: Mariner's Mirror 54. Cambridge: Cambridge University Press.

MÜLLENHOFF, K. 1906. Deutsche Altertumskunde, II. Neuer verbesserter Abdruck besorgt durch Max Roediger. Berlin: Weidmann.

MUNDT, M., ed. 1977. Hákonar saga Hákonarsonar etter Sth. 9 fol., AM 325 VIII(4) and AM 304(4). Norsk Historisk Kjeldeskrift Institutt. Norrøne tekster nr. 2. Oslo: Forlagsentralen.

NORDAL, S., ed. 1933. Egils saga Skalla-Grímssonar. Íslenzk Fornrit Vol. 2. Reykjavík: Hi] Íslenzka Fornritafélag.

ODNER, K. 1981. Comments on Economic change and the prehistoric fur trade in Northern Sweden [by A. Anderson]. Norwegian Archaeological Review 14:27-29.

- 1983. Finner og terfinner. Etniske prosesser i det nordlige Fenno-Skandinavia. Oslo Occasional Papers in Social Anthropology, Vol. 9. Oslo: Universitet i Oslo, Institutt for Sosialantropologi.

. 1985. Saamis (Lapps), Finns and Scandinavians in history and prehistory. Ethnic origins and ethnic processes in FennoScandinavia. Norwegian Archaeological Review 18:1-12.

PÁLSSON, H., and EDWARDS, P., transl. 1972. The Book of Settlements. Landnámabók. University of Manitoba Icelandic Studies, Vol. I. Winnipeg: University of Manitoba. 
PRITSAK, O. 1981. The origin of Rus'. Vol. 1: Old Scandinavian sources other than the sagas. Cambridge, Massachusetts: Harvard University Press.

ROESDAHL, E. 1991. The Vikings. London: Allen Lane, Penguin Press.

ROSS, A.S.C. 1981. The Terfinnas and Beormas of Ohthere. London: Viking Society for Northern Research.

SAWYER, P.H. 1962. The age of the Vikings. London: Edward Arnold.

SAWYER, P., and SAWYER, B. 1993. Medieval Scandinavia. Minnesota: Minnesota Press.

SIMEK, R. 1986. Elusive Elysia, or: Which way to Glæsisvellir? On the geography of the North in Icelandic legendary fiction. In: Simek, R., Kristjánsson, J., and Bekker-Nielsen, H., eds. Sagnaskemmtun. Studies in honour of Hermann Pálsson on his 65th birthday, 26th May 1986. Wien: Hermann Böhlaus Nachf. $247-275$.

. 1990. Altnordische Kosmographie. Studien und Quellen zu Weltbild und Weltbeschreibung in Norwegen und Island vom 12. bis zum 14. Jahrhundert. Ergänzungsbände zum Reallexikon der Germanischen Altertumskunde. Vol. 4. Berlin: Walter de Gruyter.

SJØVOLD, T. 1974. The Iron Age settlement of Arctic Norway. II Late Iron Age. Troms $\varnothing$ Museums Skrifter, Vol. X(2). Troms $\varnothing$ : Norwegian Universities Press.

STENVIK, L.F. 1980. Samer og nordmenn. Sett i lys av et uvanlig gravfunn fra Saltenområdet. Viking: Tidsskrift for Norrøn Arkeologi 43:127-139.
STORLI, I. 1991. De østlige smykkene fra vikingtid og tidlig middelalder. Viking: Tidsskrift for Norrøn Arkeologi 54:89-104.

STORM, G., ed. 1880. Historia Norwegiae. In: Monumenta Historica Norvegiae. Kristiania: Brøgger.

- 1888. Islandske Annaler indtil 1578. Udgivne for det norske historiske kildeskriftfond. Kristiania: Grøndahl \& Søns Bogtrykkeri (Reprint 1977, Oslo: Norsk Historisk Kjeldeskrift Institutt).

SVEINSSON, E.Ó., ed. 1954. Brennu-Njáls saga. Íslenzk Fornrit Vol. 12. Reykjavík: Hi] Íslenzka Fornritafélag.

TENNANT, P.F.D., ed. 1951. The Scandinavian book. London: William Hodge and Company Ltd.

TOLKIEN, C., transl. 1960. The saga of king Heidrek the Wise. London: Thomas Nelson and Sons Ltd.

TSCHAN, F.J., transl. 1959. Adam of Bremen. History of the archbishops of Hamburg-Bremen. New York: Columbia University Press.

URBANCZYK, P. 1992. Medieval Arctic Norway. Institute of the History of Material Culture, Polish Academy of Sciences. Warszawa: Semper.

VAUGHAN, R. 1982. The Arctic in the Middle Ages. Journal of Medieval History 8:313-342.

ZACHRISSON, I. 1985. Comments on Saamis, Finns and Scandinavians in history and prehistory. Norwegian Archaeological Review 18:19-22.

- 1991. The South Saami Culture: In archaeological finds and West Nordic written sources from AD 800-1300. In: Samson, R., ed. Social approaches to Viking studies. Glasgow: Cruithne Press. 191-199. 